\title{
A Case of Acute Renal Failure Associated with IgG4-Related Disease Presenting Both Tubulointerstitial Nephritis and Retroperitoneal Fibrosis
}

\section{Hirohito Sugawara1 ${ }^{*}$, Hideki Takizawa1, Norihito Moniwa1, Naoki Takamatsu², Yusuke Ohashi², Yayoi Ogawa ${ }^{3}$}

${ }^{1}$ Department of Nephrology, Teine-Keijinkai Hospital, Sapporo, Japan

${ }^{2}$ Department of General Internal Medicine, Teine-Keijinkai Hospital, Sapporo, Japan

${ }^{3}$ Hokkaido Renal Pathology Center, Sapporo, Japan

Email: ^a04m0532002@gmail.com

How to cite this paper: Sugawara, H., Takizawa, H., Moniwa, N., Takamatsu, N., Ohashi, Y. and Ogawa, Y. (2016) A Case of Acute Renal Failure Associated with IgG4-Related Disease Presenting Both Tubulointerstitial Nephritis and Retroperitoneal Fibrosis. Open Journal of Nephrology, 6, 86-92. http://dx.doi.org/10.4236/ojneph.2016.63011

Received: May 20, 2016

Accepted: September 25, 2016

Published: September 28, 2016

Copyright $\odot 2016$ by authors and Scientific Research Publishing Inc.

This work is licensed under the Creative Commons Attribution International License (CC BY 4.0).

http://creativecommons.org/licenses/by/4.0/

\begin{abstract}
We report a case of IgG4-related disease presenting both tubulointerstitial nephritis and retroperitoneal fibrosis causing acute renal failure in a 63-year-old male. He was admitted to our hospital because of acute renal failure requiring emergent hemodialysis. Computed tomography showed a soft-tissue density mass with an irregular border in the retroperitoneum. The mass involved bilateral ureters and had caused acute renal failure by bilateral hydronephrosis. Because of a history of uveitis and high IgG4 levels, we considered a diagnosis of retroperitoneal fibrosis, IgG4-related disease. Kidney biopsy revealed IgG4-related kidney disease with interstitial nephritis. After relief of urinary obstruction by inserting ureteral catheters into the bilateral ureters, renal function recovered.
\end{abstract}

\section{Keywords}

IgG4 Related Disease, IgG4 Related Tubulointerstitial Nephritis, Retroperitoneal Fibrosis, Acute Renal Failure

\section{Introduction}

IgG4-related disease (IgG4RD) is a relatively rare autoimmune disorder associated with elevated serum IgG4 concentration, lymphoplasmacytic infiltrate of IgG4-positive plasma cells, and storiform fibrosis in various organs including the kidneys and retroperitoneum [1]. We present a case of IgG4RD presenting both tubulointerstitial neph- 
ritis and retroperitoneal fibrosis causing acute renal failure.

\section{Case Report}

A 63-year-old male, who was diagnosed as having uveitis in another ophthalmological clinic, was admitted to our hospital because of acute renal failure. He also documented fatigue and dysuria. He had no particular prior medical history. On admission, laboratory tests showed deterioration of renal function (BUN, $68.5 \mathrm{mg} / \mathrm{dL}$; creatinine, 6.1 $\mathrm{mg} / \mathrm{dL}$; estimated glomerular filtration rate (eGFR), $8 \mathrm{~mL} / \mathrm{min} / 1.73 \mathrm{~m}^{2}$ ), increased serum total protein, proteinuria $(2.54 \mathrm{~g} /$ day $)$ and negative for hematuria in urinalysis (Table 1). Urinary N-acetyl-beta-D-glucosaminidase (NAG) and beta 2-microglobulin

Table 1. Laboratory data.

\begin{tabular}{|c|c|c|c|c|c|}
\hline$(\mathrm{CBC})$ & Result & Reference & (Immunity) & Result & Reference \\
\hline $\mathrm{RBC}$ & $414 \times 10^{4} / \mu \mathrm{L}$ & $438-577 \times 10^{4} / \mu \mathrm{L}$ & IgG4 & $240 \mathrm{mg} / \mathrm{dL}$ & $4-108 \mathrm{mg} / \mathrm{dL}$ \\
\hline $\mathrm{Hb}$ & $13.4 \mathrm{~g} / \mathrm{dL}$ & $13.6-18.3 \mathrm{~g} / \mathrm{dL}$ & $\operatorname{IgA}$ & $491 \mathrm{mg} / \mathrm{dL}$ & $90-400 \mathrm{mg} / \mathrm{dL}$ \\
\hline Plt & $18.6 \times 10^{4} / \mu \mathrm{L}$ & $14.0-37.9 \times 10^{4} / \mu \mathrm{L}$ & $\operatorname{IgM}$ & $73 \mathrm{mg} / \mathrm{dL}$ & $31-200 \mathrm{mg} / \mathrm{dL}$ \\
\hline APTT & $55.1 \mathrm{sec}$ & $26.0-38.0 \mathrm{sec}$ & ACE & $7.7 \mathrm{U} / \mathrm{L}$ & $7.0-25.0 \mathrm{U} / \mathrm{L}$ \\
\hline (Biochemistry) & & & MPO-ANCA & $(-)$ & $(-)$ \\
\hline $\mathrm{TP}$ & $8.6 \mathrm{~g} / \mathrm{dL}$ & $6.5-8.2 \mathrm{~g} / \mathrm{dL}$ & PR3-ANCA & $(-)$ & $(-)$ \\
\hline ALT & $7 \mathrm{IU} / \mathrm{L}$ & $5-45 \mathrm{U} / \mathrm{L}$ & $\mathrm{C} 4$ & $27.0 \mathrm{mg} / \mathrm{dL}$ & $11.0-34.0 \mathrm{mg} / \mathrm{dL}$ \\
\hline $\mathrm{LDH}$ & $153 \mathrm{IU} / \mathrm{L}$ & $120-245 \mathrm{U} / \mathrm{L}$ & $\mathrm{CH} 50$ & $41 \mathrm{IU} / \mathrm{mL}$ & $30-45 \mathrm{IU} / \mathrm{mL}$ \\
\hline T-Cho & $130 \mathrm{mg} / \mathrm{dL}$ & $150-219 \mathrm{mg} / \mathrm{dL}$ & (Urinalysis) & & \\
\hline TG & $51 \mathrm{mg} / \mathrm{dL}$ & $50-149 \mathrm{mg} / \mathrm{dL}$ & $\mathrm{pH}$ & 6.0 & $7.380-7.460$ \\
\hline Amy & $73 \mathrm{IU} / \mathrm{L}$ & $39-134 \mathrm{U} / \mathrm{L}$ & Up & $(2+)$ & $(-)$ \\
\hline BUN & $68.5 \mathrm{mg} / \mathrm{dL}$ & $8.0-20.0 \mathrm{mg} / \mathrm{dL}$ & Ub & $(3+)$ & $(-)$ \\
\hline $\mathrm{Cr}$ & $6.10 \mathrm{mg} / \mathrm{dL}$ & $0.65-1.09 \mathrm{mg} / \mathrm{dL}$ & NAG & $9.1 \mathrm{U} / \mathrm{L}$ & $0.0-10.0 \mathrm{U} / \mathrm{L}$ \\
\hline UA & $9.6 \mathrm{mg} / \mathrm{dL}$ & $3.6-7.0 \mathrm{mg} / \mathrm{dL}$ & $\beta 2 \mathrm{MG}$ & $491 \mu \mathrm{g} / \mathrm{L}$ & $<250 \mu \mathrm{g} / \mathrm{L}$ \\
\hline IP & $4.8 \mathrm{mg} / \mathrm{dL}$ & $2.5-4.5 \mathrm{mg} / \mathrm{dL}$ & & & \\
\hline CRP & $0.37 \mathrm{mg} / \mathrm{dL}$ & $<0.30 \mathrm{mg} / \mathrm{dL}$ & & & \\
\hline $\mathrm{HbAlc}$ & $5.20 \%$ & $4.6 \%-6.2 \%$ & & & \\
\hline
\end{tabular}


levels were $9.1 \mathrm{U} / \mathrm{L}$ and $491 \mu \mathrm{g} / \mathrm{L}$, respectively. C-reactive protein was $0.37 \mathrm{mg} / \mathrm{dL}$ and erythrocyte sedimentation rate was $53 \mathrm{~mm} / 1 \mathrm{~h}$. Serum IgG level was high $(2442 \mathrm{mg} / \mathrm{dL})$, whereas serum levels of IgA and IgM were within normal limits $(491 \mathrm{mg} / \mathrm{dL}$ and 73 $\mathrm{mg} / \mathrm{dL}$, respectively). Further analysis of IgG subclasses revealed a high IgG4 level (240 $\mathrm{mg} / \mathrm{dL}$ ). Serum angiotensin-converting enzyme (ACE) was $7 \mathrm{U} / \mathrm{mL}$. There was no hypocomplementemia (C3, $113 \mathrm{mg} / \mathrm{dL}$; C4, $27.0 \mathrm{mg} / \mathrm{dL}$; CH50, $41 \mathrm{U} / \mathrm{mL}$ ). Anti-nuclear antibody, myeloperoxidase anti-neutrophil cytoplasmic antibody (ANCA), proteinase-3 ANCA, anti-glomerular basement membrane antibody, and serum cryoglobulins were within normal ranges. A physical examination revealed no significant abnormalities. His chest and abdomen were intact and edema was not seen in his extremities. Computed tomography scanning showed a soft-tissue density mass with an irregular border in the retroperitoneum. The mass involved bilateral ureters and had caused bilateral hydronephrosis leading to acute postrenal failure (Figure 1). Because of a history of uveitis and high IgG4 levels, we considereda diagnosis of retroperitoneal fibrosis. Ga scintigraphy revealed no radionuclide uptake (Figure 2). Salivary gland biopsy showed no significant abnormalities. Kidney biopsy showed diffuse lymphoid infiltration and fibrosis. Furthermore, immunohistochemistry showed that $20 \%-30 \%$ of the plasma cells were IgG4-positive. In absolute numbers, >10 IgG4+ plasma cells were seen per HPF (Figure 3). Based on the results of a renal biopsy, the patient was diagnosed ashaving IgG4-related kidney disease (IgG4RKD). Because of acute renal failure, emergent hemodialysis was performed. After relief of urinary obstruction by inserting ureteral catheters into the bilateral ureters, renal function recovered (Figure 4). Oral prednisolone was administered at a dose of $40 \mathrm{mg}$ daily, and serum IgG4 level improved

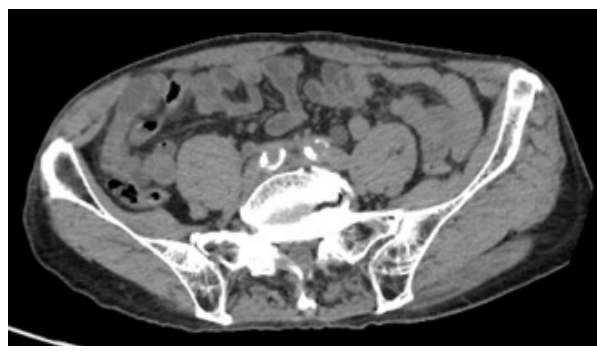

(a)

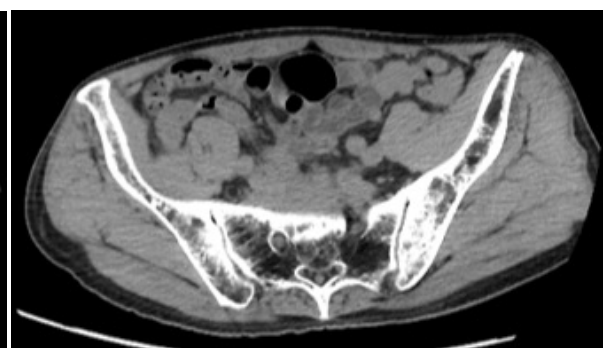

(b)

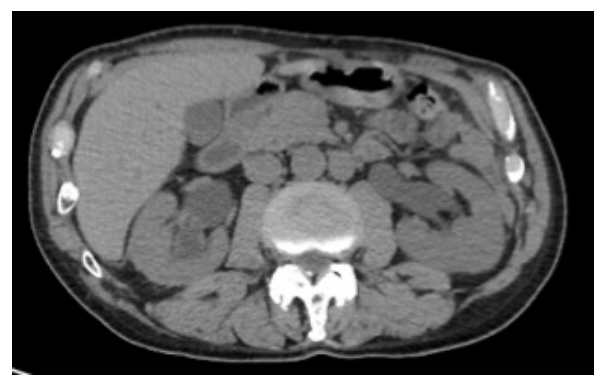

(c)

Figure 1. Computed tomography showed a soft-tissue density mass with an irregular border in the retroperitoneum (a)-(b). The mass involved bilateral ureters and had caused bilateral hydronephrosis (c). 


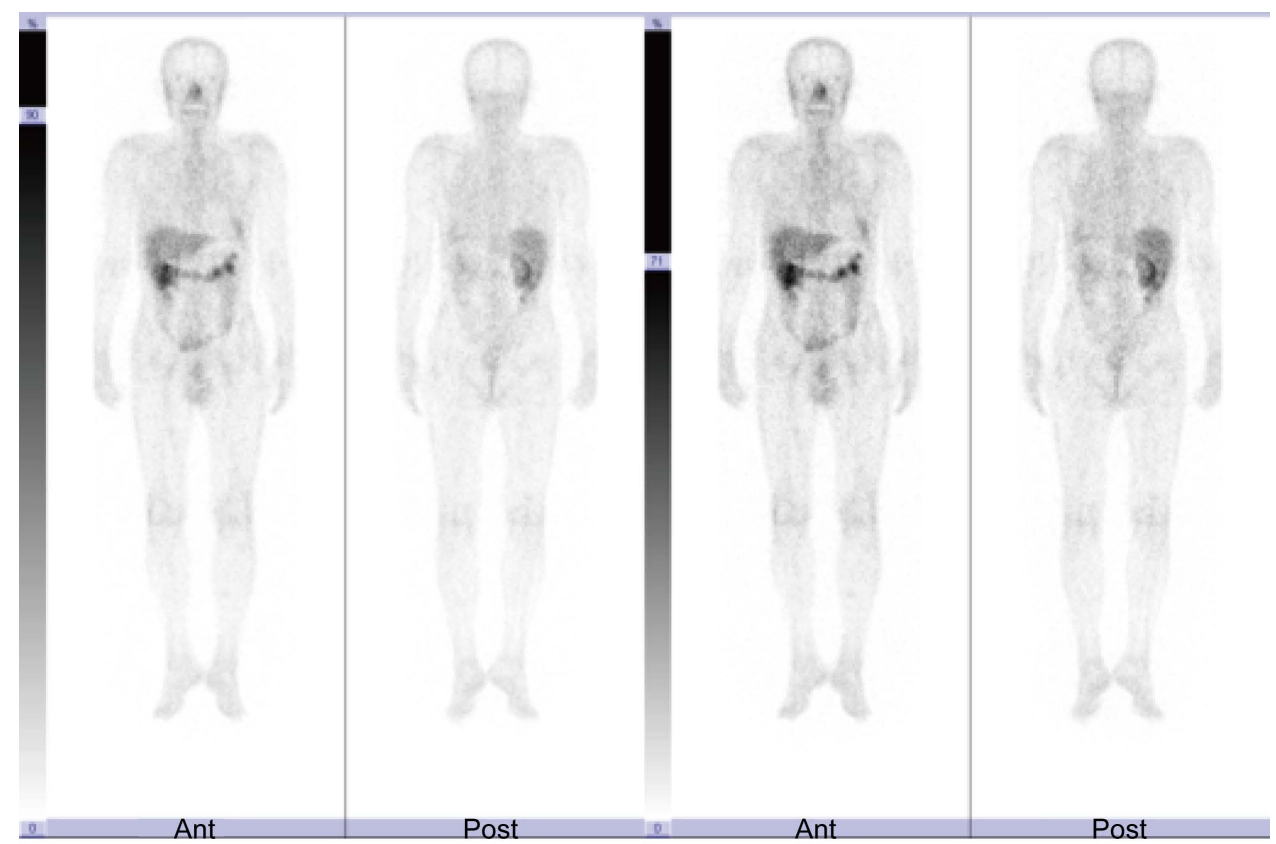

Figure 2. Ga scintigraphy revealed no radionuclide uptake.

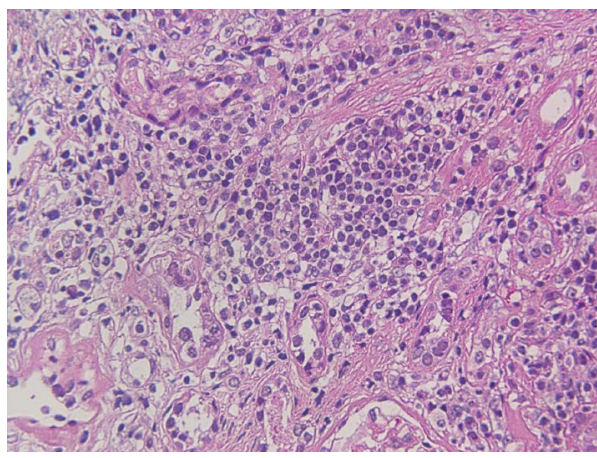

(a)

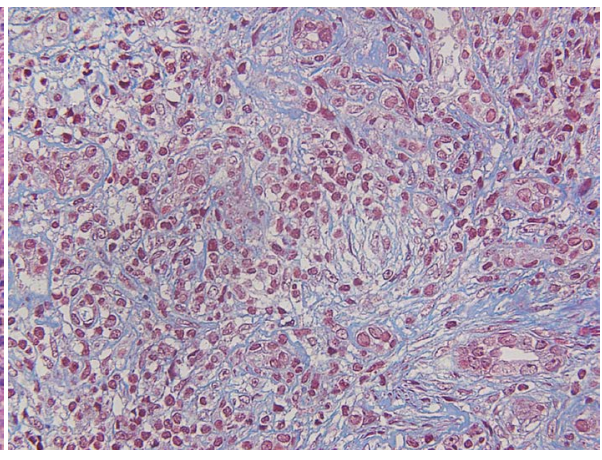

(b)

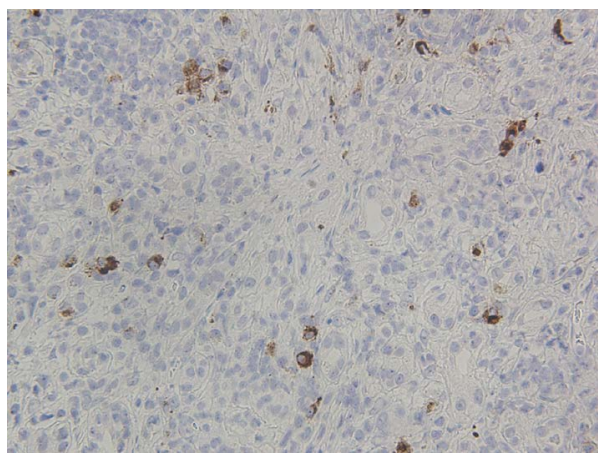

(c)

Figure 3. The infiltrate was predominantly composed of lymphocytes and plasma cells ((a), hematoxylin and eosin staining). Collagen fibers encircled the inflammatory cells ((b), Masson trichrome staining). The IgG4/IgG-positive plasma cell ratio was $20 \%-30 \%$. In absolute numbers, $>10$ IgG4+ plasma cells were seen per HPF. IgG is depicted in blue and IgG4 is depicted in brown ((c), IgG immunostaining). 


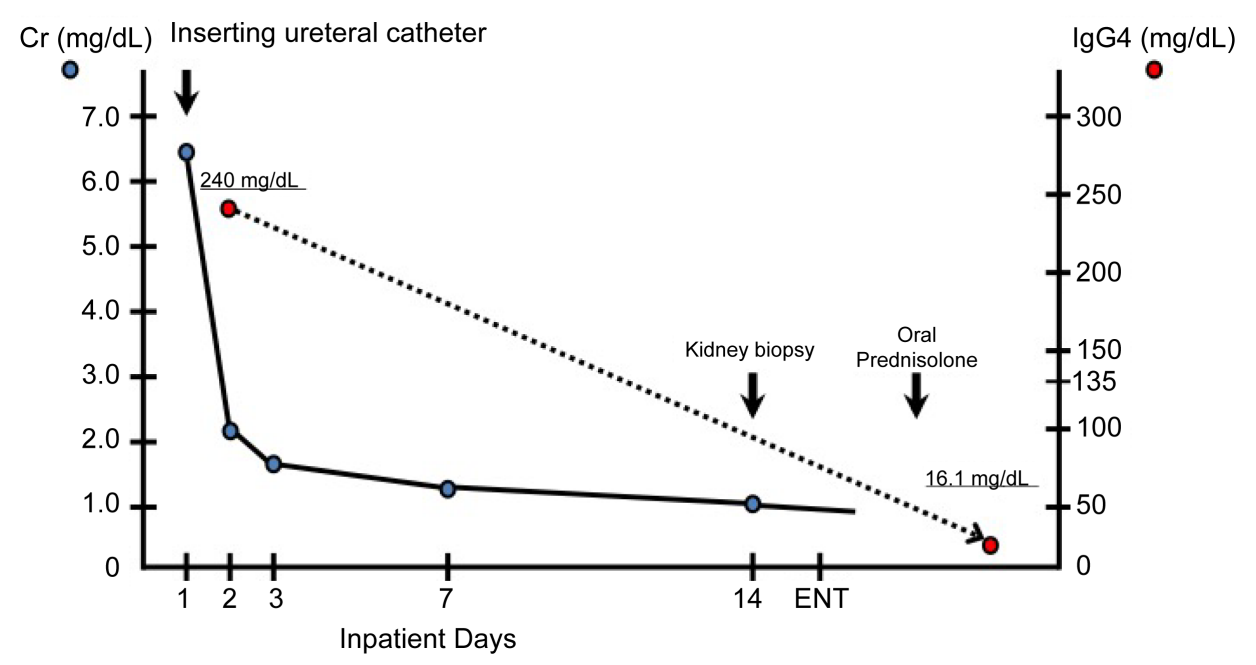

Figure 4. Clinical course.

gradually to $16.1 \mathrm{mg} / \mathrm{dL}$. He is followed up carefully and currently continued prednisolone thereafter on a tapering dose.

\section{Discussion}

IgG4RD is a multi-organ disorder characterized by infiltration of IgG4-positive plasma cells in various organs with a high level of serum IgG4. The disorder was first reported in 2001 in patients with autoimmune pancreatitis [2] and was subsequently confirmed in other organs including the salivary glands, hepatobiliary tract, lymph nodes, lungs, retroperitoneum and kidneys. IgG4RKD was first reported in 2004 as a tubulointerstitial nephritis associated with autoimmune pansreatitis [3] [4]. IgG4RKD mainly manifests as plasma cell-rich tubulointerstitial nephritis (TIN) with increased IgG4+ plasma cells and fibrosis. In a study of 153 patients with suspected IgG4RD, retrospectively collected from multiple medical centers in Japan, 23 patients (15 percent) were identified with TIN secondary to IgG4RD, all but one of whom (96 percent of TIN patients) exhibited involvement of other organs [5]. The mean age at diagnosis of the reviewed cases was 65 years, and $73 \%-87 \%$ of the patients were men [6]. Patients with IgG4RD have an increased prevalence of allergic rhinitis and bronchial asthma [7], therefore it may be allergic diathesis. The natural history of IgG4RD has not been well-defined, but in patient with IgG4RD, the incidence of malignancies is higher than that in the general population [8]. Many cases were reported in Japan, where diagnostic guidelines for IgG4RKD were proposed in 2011. The proposed five conditions are 1) presence of kidney damage, as manifested by abnormal urinalysis or urine markers and/or decreased kidney function with elevated serum IgG level, hypocomplementemia, or elevated serum IgE level; 2) abnormal renal imaging findings consisting of multiple low density lesions on enhanced computed tomography, diffuse kidney enlargement, hypovascular solitary masses in the kidney, or hypertrophic lesions of the renal pelvic wall without irregularity of the renal pelvic surface; 3) serum IgG4 level exceeding $135 \mathrm{mg} / \mathrm{dL}$; 4) renal histology showing either dense lymphoplasmacytic infiltrating IgG4-positive 
plasma cells ( $>10 \mathrm{HPF}$ ) and/or an IgG4/IgG positive plasma cell ratio $>40 \%$ or characteristic storiform fibrosis surrounding nests of lymphocytes and/or plasma cells; and 5) extrarenal histology showing dense lymphoplasmacytic infiltration with infiltrating IgG4-positive plasma cells $>10 \mathrm{HPF}$ and/or an IgG4/IgG positive plasma cell ratio < $40 \%$. The diagnosis is classified into three stages-definite, probable, and possibleaccording to the combinations of the above conditions. In the diagnostic criteria, abnormal renal imaging findings are essential for making a definitive diagnosis. In the present case, to diagnosis definitively, we had collected first from a salivary gland, however, it couldn't diagnose. Kidney biopsy, therefore, was needed. All of these conditions, including imaging showing low-density lesions, pathologic examinations showing characteristic changes, and elevated serum IgG4, led to a definitive diagnosis of IgG4RKD [9]. Since IgG4RD cannot be diagnosed by any single test, we rely on a combination of histologic, clinical, radiographic, and laboratory findings [10]. To our knowledge, there are only a few case reports of IgG4RKD with both tubulointerstitial nephritis and retroperitoneal fibrosis with acute bilateral obstructive uropathy [1] [11]-[14].

\section{Conclusion}

We experienced a case of IgG4-related disease presenting both tubulointerstitial nephritis and retroperitoneal fibrosis causing acute renal failure. A renal biopsy should be considered to make a definitive diagnosis of IgG4RKD.

\section{Contributions}

The authors contributed equally.

\section{Conflict of Interests}

The authors declare no potential conflict of interests.

\section{Consent}

Publication of this case report has been approved by the ethics committee of Teine keijinkai hospital and consent by the patient has been obtained.

\section{References}

[1] Kawano, M., Saeki, T., Nakashima, H., Nishi, S., Yamaguchi, Y., Hisano, S., et al. (2011) Diagnosis Guideline for IgG4-Related Kidney Disease. Nihon Jinzo Gakkai Shi, 53, 1062-1073.

[2] Hamano, H., Kawa, S., Horiuchi, A., Unno, H., Furuya, N., Akamatsu, T., et al. (2001) High Serum IgG4 Concentrations in Patients with Sclerosing Pancreatitis. New England Journal of Medicine, 344, 732-738. http://dx.doi.org/10.1056/NEJM200103083441005

[3] Takeda, S., Haratake, J., Kasai, T., Takeda, C. and Takazakura, E. (2004) IgG4-Associated Idiopathic Tubulointerstitial Nephritis Complicating Autoimmune Pancreatitis. Nephrology Dialysis Transplantation, 19, 474-476. http://dx.doi.org/10.1093/ndt/gfg477

[4] Uchiyama-Tanaka, Y., Mori, Y., Kimura, T., Sonomura, K., Umemura, S., Kishimoto, N., et al. (2004) Acute Tubulointerstitial Nephritis Associated with Autoimmune-Related Pan- 
creatitis. American Journal of Kidney Diseases, 43, e18-e25.

http://dx.doi.org/10.1053/j.ajkd.2003.12.006

[5] Saeki, T., Nishi, S., Imai, N., Ito, T., Yamazaki, H., Kawano, M., et al. (2010) Clinicopathological Characteristics of Patients with IgG4-Related Tubulointerstitial Nephritis. Kidney International, 78, 1016-1023. http://dx.doi.org/10.1038/ki.2010.271

[6] Kawano, M. and Saeki, T. (2015) IgG4-Related Kidney Disease-An Update. Current Opinion in Nephrology and Hypertension, 24, 193-201. http://dx.doi.org/10.1097/MNH.0000000000000102

[7] Masaki, Y., Dong, L., Kurose, N., Kitagawa, K., Morikawa, Y., Yamamoto, M., et al. (2009) Proposal for a New Clinical Entity, IgG4-Positive Multiorgan Lymphoproliferative Syndrome Analysis of 64 Cases of IgG4-Related Disorders. Annals of the Rheumatic Diseases, 68, 1310-1315. http://dx.doi.org/10.1136/ard.2008.089169

[8] Yamamoto, M., Takahashi, H., Tabeya, T., Suzuki, C., Naishiro, Y., Ishigami, K., et al. (2012) Risk of Malignancies in IgG4-Related Disease. Modern Rheumatology, 22, 414-418. http://dx.doi.org/10.3109/s10165-011-0520-x

[9] Kawano, M., Saeki, T., Nakashima, H., Nishi, S., Yamaguchi, Y., Hisano, S., et al. (2011) Proposal for Diagnostic Criteria for IgG4-Related Kidney Disease. Clinical and Experimental Nephrology, 15, 615-626. http://dx.doi.org/10.1007/s10157-011-0521-2

[10] Raissian, Y., Nasr, S.H., Larsen, C.P., Colvin, R.B., Smyrk, T.C., Takahashi, N., et al. (2011) Diagnosis of IgG4-Related Tubulointerstitial Nephritis. Journal of the American Society of Nephrology, 22, 1343-1352. http://dx.doi.org/10.1681/ASN.2011010062

[11] Kawano, M., Mizushima, I., Yamaguchi, Y., Imai, N., Nakashima, H., Nishi, S., et al. (2012) Immunohistochemical Characteristics of IgG4-Related Tubulointerstitial Nephritis Detailed Analysis of 20 Japanese Cases. International Journal of Rheumatology, 2012, Article ID: 609795. http://dx.doi.org/10.1155/2012/609795

[12] Yamaguchi, Y., Kanetsuna, Y., Honda, K., Yamanaka, N., Kawano, M. and Nagata, M. (2012) Japanese Study Group on IgG4-Related Nephropathy. Characteristic Tubulointerstitial Nephritis in IgG4-Related Disease. Human Pathology, 43, 536-549.

http://dx.doi.org/10.1016/j.humpath.2011.06.002

[13] Katano, K., Hayatsu, Y., Matsuda, T., Miyazaki, R., Yamada, K., Kawano, M., et al. (2007) Endocapillary Proliferative Glomerulonephritis with Crescent Formation and Concurrent Tubulointerstitial Nephritis Complicating Retroperitoneal Fibrosis with a High Serum Level of IgG4. Clinical Nephrology, 68, 308-314. http://dx.doi.org/10.5414/CNP68308

[14] Saeki, T., Kawano, M., Mizushima, I., Yamamoto, M., Wada, Y., Nakashima, H., et al. (2013) The Clinical Course of Patients with IgG4-Related Kidney Disease. Kidney International, 84, 826-833. http://dx.doi.org/10.1038/ki.2013.191 
Submit or recommend next manuscript to SCIRP and we will provide best service for you:

Accepting pre-submission inquiries through Email, Facebook, LinkedIn, Twitter, etc. A wide selection of journals (inclusive of 9 subjects, more than 200 journals)

Providing 24-hour high-quality service

User-friendly online submission system

Fair and swift peer-review system

Efficient typesetting and proofreading procedure

Display of the result of downloads and visits, as well as the number of cited articles

Maximum dissemination of your research work

Submit your manuscript at: http://papersubmission.scirp.org/

Or contact ojneph@scirp.org 